\title{
PENGEMBANGAN APLIKASI "EDCOUNTING-APP" SEBAGAI MEDIA PEMBELAJARAN AKUNTANSI KEUANGAN
}

\author{
DEVELOPING APPLICATION "EDCOUNTING-APP” AS MEDIA TO LEARN \\ FINANCIAL ACCOUNTING SUBJECT
}

Oleh:

RR. Trianina Arini Kudiasanti

Pendidikan Akuntansi Universitas Negeri Yogyakarta ninaarini94@gmail.com

Sukirno

Staf Pengajar Jurusan Pendidikan Akuntansi Universitas Negeri Yogyakarta

\begin{abstract}
Abstrak
Tujuan dari penelitian ini adalah mengembangkan aplikasi edukatif berbasis Android dan Desktop "Edcounting-App" sebagai media pembelajaran Akuntansi Keuangan. Metode penelitian yang digunakan dalam pengembangan aplikasi edukatif berbassis Android dan Desktop "EdcountingApp" sebagai media pembelajaran Akuntansi Keuangan adalah jenis penelitian pengembangan dengan metode ADDIE. Penilaian siswa kelas XI Ak 1 dan XI Ak 2 SMK Negeri 7 Yogyakarta yang terdiri dari 54 siswa memperoleh nilai rata-rata seluruh aspek sebesar 2,99 yang termasuk dalam kategori Layak. Berdasarkan seluruh penilaian terhadap kelayakan aplikasi dari ahli media sebesar 3,44, penilaian dari ahli materi sebesar 3, penilaian dari praktisi pembelajaran Akuntansi sebesar 2,93, dan penilaian siswa kelass XI Ak SMK Negeri 7 Yogyakarta sebesar 2,99, maka aplikasi edukatif berbasis Android dan Desktop "Edcounting-App" Layak dipergunakan sebagai media pembelajaran Akuntansi Keuangan.
\end{abstract}

Kata Kunci: Aplikasi Edukatif "Edcounting-App”, Android dan Desktop, Media, ADDIE.

\begin{abstract}
The aim of this research is developing educative android and desktop based application "Edcounting-App" as media to learn financial accounting subject. Research method that was used in developing the application "Edcounting-App" was Research and Development with ADDIE method. The assessment of grade XI Ak 1 students and XI Ak 2 students of SMK Negeru 7 Yogyakarta that consist of 54 students got 2,99 as an average score of all aspects that can be categorized as feasible. Based on all assessments on the feasibility of the application from experts of media that got 3,44, from expert of material that got 3, from the practitioner of accounting teaching that got 2,93, and from students of XI Ak class of SMK Negeri 7 Yogyakarta that got 2,99, it can be concluded that educative android and desktop based application "Edcounting-App" is feasible to be used as media to learn financial accounting subject.
\end{abstract}

Keywords: Educative A pplication "Edcounting-App”, Android and Desktop, Media 


\section{PENDAHULUAN}

Pemerintah telah melakukan berbagai upaya dalam memperbaiki kualitas Sumber Daya Manusia (SDM) melalui kualitas pendidikan nasional. Salah satu bidang studi yang mengalami perkembangan teknologi adalah akuntansi. Akuntansi adalah seni pencatatan dan pengikhtisaran transaksi keuangan dan penafsiran akibat suatu transaksi terhadap kekuatan ekonomi (Sumadji, 2006: 16). Bidang akuntansi banyak dijadikan sebagai salah satu bidang studi favorit di sekolah-sekolah, universitasuniversitas dan instansi-instansi. Meskipun demikian, sering kali mata pelajaran akuntansi dianggap sulit oleh para siswasiswi di sekolah.

Dewasa ini, ketika ilmu pengetahuan dan teknologi berkembang sangat pesat, proses pembelajaran tidak lagi di monopoli oleh kehadiran guru di dalam kelas. Siswa dapat belajar di mana saja dan kapan saja. Siswa bisa belajar apa saja sesuai dengan minat dan gaya belajar masing-masing siswa yang berbeda. Seorang desainer pembelajaran dituntut untuk dapat merancang pembelajaran dengan memanfaatkan berbagai jenis media dan sumber belajar yang sesuai agar proses pembelajaran berlangsung secara menyenangkan, efektif, dan efisien.

Rossi dan Biddle (1966: mengemukakan bahwa media pembelajaran adalah seluruh alat dan bahan yang dapat dipakai untuk tujuan pendidikan, seperti radio, televisi, buku, koran, majalah, dan sebagainya. Secara lebih khusus, pengertian media dalam proses belajar mengajar cenderung diartikan sebagai alat-alat grafis, photografis, atau elektronis untuk menangkap, memproses, dan menyusun kembali informasi visual atau verbal.

Nana Sudjana dan Ahmad Rivai (2013: 2) mengemukakan manfaat media pembelajaran dalam proses belajar siswa pembelajaran akan lebih menarik perhatian siswa sehingga dapat menumbuhkan motivasi belajar, selain itu bahan pembelajaran akan lebih jelas maknanya sehingga dapat lebih dipahami oleh siswa dan memungkinkannya menguasai dan mencapai tujuan pembelajaran. Manfaat lainnya yaitu, metode mengajar akan lebih bervariasi, tidak semata-mata komunikasi verbal melalui penuturan kata-kata oleh guru, sehingga siswa tidak bosan dan guru tidak kehabisan tenaga, apalagi kalau guru mengajar pada setiap jam pelajaran. Siswa juga dapat lebih banyak melakukan kegiatan belajar sebab tidak hanya mendengarkan uraian guru, tetapi juga aktivitas lain seperti mengamati, melakukan, mendemonstrasikan, memerankan, dan lainlain.

Berdasarkan latar belakang di atas, dapat diidentifikasi bahwa masalah dalam penelitian ini, yakni siswa mengalami hambatan dalam memahami materi dan menganggap bahwa pembelajaran Akuntansi merupakan sesuatu yang rumit, sulit, dan membosankan bagi siswa, media pembelajaran yang digunakan terbatas pada buku paket dan latihan soal, media pembelajaran Akuntansi kurang beragam dan inovatif, serta proses pembelajaran cenderung monoton dan satu arah mengakibatkan siswa cepat bosan.

Aplikasi yang akan dibuat oleh peneliti bernama "Edcounting-App" yang merupakan singkatan dari Educative Accounting Application. Aplikasi tersebut merupakan inovasi yang dibuat oleh peneliti sebagai media untuk mempermudah proses pembelajaran akuntansi dan dapat digunakan sebagai media evaluasi bagi guru untuk siswa melalui forum group discusion, task dan quiz berbasis Android dan Desktop. "Edcounting-App" nantinya dapat diakses melalui laptop (desktop) maupun Smartphone Android dengan sistem aplikasi sosial media yang di dalamnya terdapat game berisi soal-soal akuntansi. Aplikasi ini dibuat menggunakan program Android Studio dengan bahasa pemrograman Java untuk aplikasi Android dan menggunakan program Visual Studio 2015 untuk aplikasi Desktop. 
Android merupakan sistem operasi yang dikembangkan untuk perangkat mobile berbasis Linux. Pada awalnya sistem operasi ini dikembangkan oleh Android Inc. Yang kemudian dibeli oleh Google pada tahun 2005 (Stephanus Hermawan, 2011:2). Kemajuan media komputer memberikan beberapa kelebihan untuk kegiatan produksi audio visual. Pada tahun-tahun belakangan komputer mendapat perhatian besar karena kemampuannya yang dapat digunakan dalam bidang kegiatan pembelajaran. Ditambah dengan teknologi jaringan dan internet, komputer seakan menjadi primadona dalam kegiatan pembelajaran (Daryanto, 2013: 146).

Penelitian ini difokuskan untuk mengukur kelayakan media pembelajaran, tidak sampai pada tahap evaluasi. Penelitian ini bertujuan untuk mengetahui cara pengembangan produk aplikasi edukatif berbasis Android dan Desktop "EdcountingApp" dengan model pengembangan ADDIE, mengetahui penilaian siswa mengenai aplikasi Edcounting-App, dan mengetahui kelayakan produk "EdcountingApp".

\section{METODE PENELITIAN}

Jenis penelitian ini adalah Penelitian dan pengembangan. Penelitian dan pengembangan adalah metode penelitian yang digunakan untuk menghasilkan produk tertentu, dan menguji keefektifan produk tersebut (Sugiyono, 2013: 407). Penelitian dan pengembangan dipilih karena peneliti bertujuan menghasilkan suatu produk baru dalam media pembelajaran Akuntansi Keuangan dalam bentuk aplikasi edukatif berbasis Android dan Desktop "EdcountingApp" untuk siswa SMK Negeri 7 Yogyakarta, maka dari itu peneliti juga ingin menguji kelayakan produk yang telah dihasilkan tersebut.

Penelitian dilaksanakan pada bulan Oktober 2016, bertembat di SMK Negeri 7 Yogyakarta dengan alamat Jl. Gowongan Kidul JT.III/416, Daerah Istimewa Yogyakarta. Subjek uji coba yang terlibat adalah satu orang ahli media, satu orang ahli materi Akuntansi Keuangan, satu orang praktisi pembelajaran Akuntansi Keuangan (guru pengampu Akuntansi Keuangan kelas XI Ak SMK Negeri 7 Yogyakarta), dan 2 kelas yang masing-masing terdiri dari 32 siswa kelas XI Ak SMK Negeri 1 Yogyakarta. Uji coba yang diteliti adalah kualitas dan kelayakan media pembelajaran berupa aplikasi edukatif berbasis Android dan Desktop "Edcounting-App" yang merupakan aspek relevansi materi, aspek soal latihan, aspek bahasa, aspek tampilan visual, aspek rekayasa perangkat lunak, dan aspek bagi strategi pembelajaran.

Prosedur penelitian ini mengadaptasi model pengembangan ini mengadaptasi model pengembangan ADDIE. Peneliti memilih model pengembangan ADDIE karena jenis penelitian ini sesuai dengan kebutuhan peneliti untuk mencapai tujuan yang telah dibuat. ADDIE merupakan singkatan dari Analysis, Design, Development or Production, Implementation or Delivery and Evaluations (Endang Mulyatiningsih, 2013: 199). Data yang akan dikumpulkan dalam penelitian ini terdiri dari dua data, yaitu data kualitatif dan kuantitatif.

Instrumen yang digunakan dalam pengumpulan data pada penelitian ini yaitu angket atau kuesioner. Angket adalah instrumen penelitian yang berisi serangkaian pertanyaan atau pernyataan untuk menjaring data atau informasi yang harus dijawab responden secara bebas sesuai dengan pendapatnya (Zainal Arifin, 2014: 228). Jenis instrumen angket dipilih oleh peneliti karena manfaat dari angket sesuai dengan kebutuhan peneliti untuk mendapatkan data yang dibutuhkan. Kisi-kisi angket bersumber dari aspek dan indikator penilaian media pembelajaran milik Romi Satria Wahono (2006) dengan modifikasi yang dilakukan oleh peneliti.

Data yang telah terkumpul kemudian dianalisis untuk mengetahui penilaian dan pendapat dari produk yang dihasilkan. Data penilaian kualitas produk diperoleh dari 
hasil isian angket oleh ahli media, ahli materi, dan praktisi pembelajaran. Data selanjutnya dianalisis dengan mengubah penilaian kualitatif menjadi kuantitatif dengan ketentuan:

\begin{tabular}{|l|c|}
\hline \multicolumn{1}{|c|}{ Kategori } & Skor \\
\hline SS (Sangat Setuju) & 4 \\
\hline S (Setuju) & 3 \\
\hline KS (Kurang Setuju) & 2 \\
\hline TS (Tidak Setuju) & 1 \\
\hline
\end{tabular}

Setelah mengubah penilaian, kemudian menghitung rata-rata skor tiap indikator dengan rumus:

$$
\bar{\chi}=\frac{\sum \chi}{N}
$$

Keterangan:

$$
\bar{\chi}=\text { skor rata-rata }
$$

$\sum \chi=$ jumlah skor

$N=$ jumlah subjek uji coba

(Eko Putro Widoyoko, 2014: 237)

Langkah terakhir, menginterpretasikan secara kualitatif jumlah rerata skor tiap aspek dengan menggunakan kriteria sebagai berikut:

Presentase kelayakan $(\%)=\frac{\sum \text { hasil skor angket }}{\sum \text { skor yang ideal }} \times 100 \%$

Suharsimi Arikunto (2010: 210)

Data skor rata-rata yang terkumpul diubah menjadi nilai kualitatif dengan kriteria yang telah ditentukan sebagai berikut.

Sumber: Eko Putro Widoyoko, (2014: 238)

\begin{tabular}{|c|l|l|}
\hline Nilai & \multicolumn{1}{|c|}{ Rentang Skor } & \multicolumn{1}{|c|}{ Kategori } \\
\hline $\mathrm{A}$ & $\mathrm{X}>\mathrm{Xi}+1,8 \times \mathrm{sbi}$ & $\begin{array}{l}\text { Sangat } \\
\text { layak }\end{array}$ \\
\hline $\mathrm{B}$ & $\begin{array}{l}\mathrm{Xi}+0,6 \times \mathrm{sbi}<\mathrm{X} \leq \\
\mathrm{Xi}+1,8 \times \mathrm{sbi}\end{array}$ & Layak \\
\hline $\mathrm{C}$ & $\begin{array}{l}\mathrm{Xi}-0,6 \times \mathrm{sbi}<\mathrm{X} \leq \\
\overline{X i}+0,6 \times \mathrm{sbi}\end{array}$ & Cukup \\
\hline $\mathrm{D}$ & $\begin{array}{l}\mathrm{Xi}-1,8 \times \mathrm{sbi}<\mathrm{X} \leq \\
\mathrm{Xi}-0,6 \times \mathrm{sbi}\end{array}$ & Kurang \\
\hline $\mathrm{E}$ & $\mathrm{X} \leq \mathrm{Xi}-1,8 \times \mathrm{sbi}$ & $\begin{array}{l}\text { Sangat } \\
\text { Kurang } \\
\text { Layak }\end{array}$ \\
\hline
\end{tabular}

\section{HASIL PENELITIAN DAN PEMBA- HASAN}

Hasil pengamatan peneliti, penggunaan smarthphone cenderung menyita waktu belajar dan konsentrasi siswa terhadap pelajaran karena dipergunakan untuk mengakses berbagai macam sosial media, bermain game, mendengarkan musik, ataupun bermain fitur menghibur lainnya. Pembuatan media pembelajaran ini menggunakan perangkat keras (hardware) Intel Core i7 6700k, RAM 16GB, Hard disk 2 TB, serta perangkat lunak (software) berupa Android Studio, Webstrom+njws, dan coding secara manual. Materi yang dimuat dalam media sesuai dengan standar isi yang ditetapkan oleh Badan Standar Nasional Pendidikan (BSNP). Materi mengelola kartu piutang pada akuntansi keuangan sesuai dengan Standar Kompetensi (SK) dan Kompetensi Dasar (KD) Mengelola Kartu Piutang.

Tahap desain merupakan tahap perancangan media yang meliputi pembuatan desain media secara keseluruhan (storyboard), penyusunan materi, soal dan jawaban, pembuatan logo, backround, gambar, dan tombol yang akan digunakan.

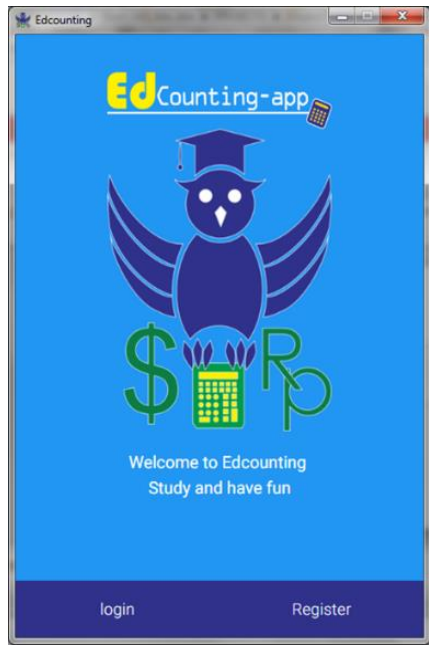

Gambar 1. Tampilan

awal Edcounting-App 


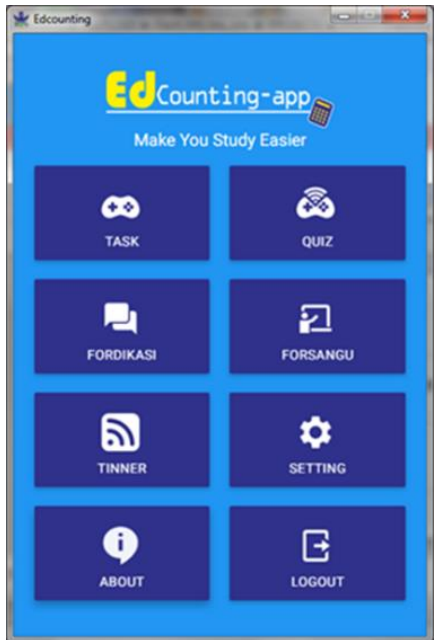

Gambar 2. Tampilan Menu EdcountingApp

Semua fungsi dalam media pembelajaran "Edcounting-App" berbasis android dan desktop ini dapat berjalan sesuai dengan rancangan pembuatan media melalui proses coding secara manual.

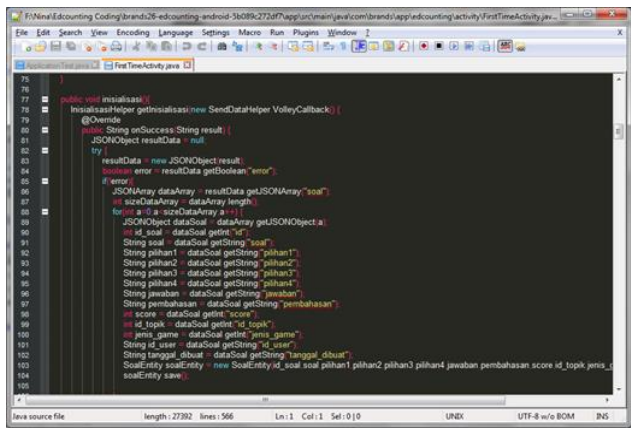

\section{Gambar 3. Contoh Coding pada Edcounting-App}

Tahap yang selanjutnya adalah pengujian media pembelajaran yang telah dibuat. Pengujian sangat penting karena tahap ini bertujuan untuk mengetahui apakah fungsi-fungsi dalam aplikasi dapat berjalan dengan benar dan mengetahui kekurangan atau kesalahan yang harus diperbaiki. Pengujian aplikasi ini dilakukan dengan mentransfer file Android Package (.apk) melalui koneksi internet ke perangkat smarthphone Infinix Hot Note dengan spesifikasi CPU : 1,4 GHz Octacore CortexA53 Mediatek, Operating System versi 4.4.4 (Kitkat), RAM 2 GB dan ke desktop berupa
Laptop HP 11-F105TU dengan spesifikasi Intel Celeron Processor N2840 2,16 GHz, RAM GB DDR 3, Windows 10.

Validasi media dilakukan oleh media yang bertujuan untuk memberikan perbaikan dan saran. Hasil validasi ahli media dapat dilihat dalam tabel berikut.

\section{Tabel 1. Hasil Validasi Ahli Media}

\begin{tabular}{|c|l|l|l|l|}
\hline $\begin{array}{c}\text { N } \\
\text { o }\end{array}$ & \multicolumn{1}{|c|}{$\begin{array}{c}\text { Aspek } \\
\text { Penilaian }\end{array}$} & $\begin{array}{c}\text { Jum- } \\
\text { lah } \\
\text { Skor }\end{array}$ & $\begin{array}{c}\text { Rata- } \\
\text { rata } \\
\text { Skor }\end{array}$ & Kategori \\
\hline 1 & $\begin{array}{l}\text { Rekayasa } \\
\text { Perangkat } \\
\text { Lunak }\end{array}$ & 19 & 2,71 & $\begin{array}{l}\text { Cukup } \\
\text { Layak }\end{array}$ \\
\hline 2 & $\begin{array}{l}\text { Desain } \\
\text { Pembela- } \\
\text { jaran }\end{array}$ & 37 & 3,08 & Layak \\
\hline 3 & $\begin{array}{l}\text { Komuni- } \\
\text { kasi } \\
\text { Visual }\end{array}$ & 6 & 3 & Layak \\
\hline \multicolumn{2}{|l|}{ Total } & 62 & 2,93 & Layak \\
\hline
\end{tabular}

Validasi ahli materi digunakan untuk menilai materi yang telah disusun dalam aplikasi Edcounting-App. Berdasarkan hasil validasi ahli materi dapat dilihat pada tabel berikut.

Tabel 2. Hasil Validasi Ahli Materi

\begin{tabular}{|c|c|c|c|c|}
\hline No & $\begin{array}{c}\text { Aspek } \\
\text { Penilaian }\end{array}$ & $\begin{array}{l}\text { Jum- } \\
\text { lah } \\
\text { Skor }\end{array}$ & $\begin{array}{l}\text { Rata } \\
\text {-rata } \\
\text { Skor }\end{array}$ & Kategori \\
\hline 1 & Materi & 24 & 3 & Layak \\
\hline 2 & Soal & 18 & 3 & Layak \\
\hline 3 & $\begin{array}{l}\text { Kebaha- } \\
\text { saan }\end{array}$ & 9 & 3 & Layak \\
\hline 4 & $\begin{array}{l}\text { Keterlak- } \\
\text { sanaan }\end{array}$ & 9 & 3 & Layak \\
\hline \multicolumn{2}{|c|}{ Total } & 60 & 3 & Layak \\
\hline
\end{tabular}

Proses validasi dilakukan oleh praktisi pembelajaran Akuntansi Keuangan kelas XI Ak di SMK Negeri 7 Yogyakarta, yaitu ibu Dra. Nurwahyuniati Rokhmi. Validasi oleh praktisi pembelajaran Akuntansi dapat dilihat pada tabel berikut. 
Tabel 3. Hasil Validasi Praktisi Pembelajaran Akuntansi

\begin{tabular}{|l|l|l|l|l|}
\hline No & $\begin{array}{c}\text { Aspek } \\
\text { Penilaian }\end{array}$ & $\begin{array}{c}\text { Jumlah } \\
\text { Skor }\end{array}$ & $\begin{array}{c}\text { Rata- } \\
\text { rata } \\
\text { Skor }\end{array}$ & $\begin{array}{c}\text { Kate- } \\
\text { gori }\end{array}$ \\
\hline 1 & $\begin{array}{l}\text { Rekayasa } \\
\text { Perangkat } \\
\text { Lunak }\end{array}$ & 19 & 2,71 & $\begin{array}{l}\text { Cukup } \\
\text { Layak }\end{array}$ \\
\hline 2 & $\begin{array}{l}\text { Desain } \\
\text { Pembelaj } \\
\text { aran }\end{array}$ & 37 & 3,08 & Layak \\
\hline 3 & $\begin{array}{l}\text { Komunik } \\
\text { asi Visual }\end{array}$ & 6 & 3 & Layak \\
\hline \multicolumn{2}{|l|}{ Total } & 62 & 2,93 & Layak \\
\hline
\end{tabular}

Tahap implementasi pada produk ini diuji cobakan di dalam 2 kelas yang masingmasing kelas berisi 32 siswa dari SMK Negeri 7 Yogyakarta, namun pada saat implementasi berlangsung ada siswa yang tidak hadir karena sedang mengikuti kegiatan di luar sekolah. Pada tahap ini produk di uji cobakan dua kali, pertama untuk aplikasi berbasis Android dan yang kedua untuk aplikasi berbasis Desktop pada subjek penelitian yang sama. Uji coba produk berbasis Android akan dilakukan dengan Smartphone Android yang dimiliki masing-masing siswa, sedangkan produk berbasis Desktop akan menggunakan komputer di Lab Komputer yang dimiliki SMK Negeri 7 Yogyakarta. Hasil penilaian siswa selengkapnya dapat dilihat pada tabel berikut.

Tabel 4. Hasil Penilaian XI AK 1

\begin{tabular}{|l|l|l|l|l|}
\hline $\begin{array}{c}\mathbf{N} \\
\mathbf{0}\end{array}$ & $\begin{array}{c}\text { Aspek } \\
\text { Penilaian }\end{array}$ & $\begin{array}{c}\text { Jum- } \\
\text { lah } \\
\text { Skor }\end{array}$ & $\begin{array}{c}\text { Rata- } \\
\text { rata } \\
\text { Skor }\end{array}$ & $\begin{array}{c}\text { Kate- } \\
\text { gori }\end{array}$ \\
\hline 1 & $\begin{array}{l}\text { Rekayasa } \\
\text { Perangkat } \\
\text { Lunak }\end{array}$ & 498 & 2,45 & $\begin{array}{l}\text { Cukup } \\
\text { Layak }\end{array}$ \\
\hline 2 & $\begin{array}{l}\text { Desain } \\
\text { Pembelaj } \\
\text { aran }\end{array}$ & 1.01 & 3,31 & Layak \\
\hline 3 & $\begin{array}{l}\text { Komunik } \\
\text { asi Visual }\end{array}$ & 187 & 3,22 & Layak \\
\hline Total & $\begin{array}{l}1.70 \\
4\end{array}$ & 3,00 & Layak \\
\hline
\end{tabular}

Secara keseluruhan hasil penilaian siswa kelas XI Ak 1 SMK Negeri 7 Yogyakarta diperoleh skor rata-rata 3 yang masuk ke dalam rentang $\mathrm{X}>2,8$ dengan kategori layak. Sehingga tingkat kelayakan media pembelajaran "Edcounting-App" berdasarkan hasil penilaian siswa kelas XI Ak 1 SMK Negeri 7 Yogyakarta masuk ke dalam kategori Layak.

Tabel 5. Hasil Penilaian XI AK 2

\begin{tabular}{|l|l|l|l|l|}
\hline No & $\begin{array}{c}\text { Aspek } \\
\text { Penilaian }\end{array}$ & $\begin{array}{c}\text { Jumlah } \\
\text { Skor }\end{array}$ & $\begin{array}{c}\text { Rata- } \\
\text { rata } \\
\text { Skor }\end{array}$ & Kategori \\
\hline 1 & $\begin{array}{l}\text { Rekayasa } \\
\text { Perangkat } \\
\text { Lunak }\end{array}$ & 448 & 2,56 & $\begin{array}{l}\text { Cukup } \\
\text { Layak }\end{array}$ \\
\hline 2 & $\begin{array}{l}\text { Desain } \\
\text { Pembelajaran }\end{array}$ & 877 & 3,19 & Layak \\
\hline 3 & $\begin{array}{l}\text { Komunikasi } \\
\text { Visual }\end{array}$ & 160 & 3,20 & Layak \\
\hline \multicolumn{2}{|l|}{ Total } & 1.485 & 2,98 & Layak \\
\hline
\end{tabular}

Secara keseluruhan hasil penilaian siswa kelas XI Ak 2 SMK Negeri 7 Yogyakarta diperoleh skor rata-rata 2,98 yang masuk ke dalam rentang $\mathrm{X}>2,8$ dengan kategori layak. Sehingga tingkat kelayakan media pembelajaran "Edcounting-App" berdasarkan penilaian siswa kelas XI Ak 2 SMK Negeri 7 Yogyakarta masuk ke dalam kategori Layak.

Hasil penelitian menunjukkan penilaian dari ahli media sebesar 3,44 masuk dalam kategori Sangat Layak, penilaian dari ahli materi sebesar 3 masuk ke dalam kategori Layak, penilaian dari praktisi pembelajaran Akuntansi sebesar 2,93 masuk ke dalam kategori Layak, serta penilaian siswa kelas XI Ak 1 dan Ak 2 SMK Negeri 7 Yogyakarta memperoleh rata-rata sebesar 2,99 masuk dalam kategori Layak. Berdasarkan penilaian keempat subjek penelitian tersebut, maka aplikasi edukatif berbasis Android dan Desktop "EdcountingApp" Layak dipergunakan sebagai media pembelajaran Akuntansi Keuangan. Pada 
penelitian ini, tahap evaluasi tidak dijalankan, karena penelitian ini hanya berfokus pada uji kelayakan aplikasi saja.

Media akhir dari penelitian ini berupa aplikasi edukatif berbasis android dan desktop "Edcounting-App" dengan materi sementara Pengelolaan Kartu Piutang. Materi bisa dikurangi dan ditambah kapan pun sesuai dengan kebutuhan pengguna, dalam hal ini adalah guru Akuntansi Keuangan. Aplikasi ini merupakan media pembelajaran yang dapat dipergunakan sebagai sarana berlatih soal maupun berdiskusi mengenai materi Akuntansi.

Aplikasi edukatif berbasis android dan desktop "Edcounting-App" merupakan produk akhir dapat digunakan siapa saja dengan menggunakan smarthphone android dan desktop berupa Personal Computer maupun Laptop. Aplikasi edukatif berbasis android dan desktop "Edcounting-App" pengoperasiannya tergolong mudah karena telah disesuaikan dengan standar operasional pada aplikasi Android pada umumnya. Aplikasi edukatif berbasis android dan desktop "Edcounting-App" memiliki kelebihan dan kekurangan sebagai media pembelajaran.

Kelebihan media ini antara lain aplikasi "Edcounting-App" merupakan media pembelajaran Akuntansi yang tidak hanya disajukan dalam smarthphone, melainkan dapat dipergunakan juga pada desktop (PC atau Laptop) apabila sekolah tidak mengijinkan siswanya membawa atau mempergunakan smarthphone di sekolah. Kelebihan lainnya, Materi yang berada dalam aplikasi "Edcounting-App" tidak hanya terbatas pada materi yang telah disediakan peneliti, melainkan dapat disesuaikan dengan materi yang dibutuhkan oleh guru dan siswa. Aplikasi edukatif berbasis android dan desktop "EdcountingApp" mudah dibawa kemana saja dan dapat digunakan kapan saja, sehingga guru tetap dapat mengambil nilai siswa atau memberikan materi kepada siswa meskipun sedang tidak bertatap muka.
Kekurangan media ini antara lain aplikasi edukatif berbasis android dan desktop "Edcounting-App" harus menggunakan koneksi internet agar dapat digunakan, apabila jaringan tidak stabil maka kemungkinan aplikasi akan eror meskipun tidak selalu demikian. Kemuadian, belum adanya fitur untuk memisahkan materi dari beragam sekolah, sehingga apabila dipergunakan dibananyak sekolah dan materi yang berbeda masih berpotensi menimbulkan kebingungan pada siswa untuk mencari yang berasal dari sekolahnya sendiri. Kelemahan lainnya yakni belum dapat diunduh di playstore, sehingga jika ada pembaharuan fitur harus diunduh secara manual.

Adapun keterbatasan dalam pengembangan media pembelajaran "Edcounting-App" meliputi produk media pembelajaran "Edcounting-App" yang dihasilkan masih termasuk pengembangan tingkat awal, hanya mencakup materi yang sangat sederhana untuk sementara karena materi selebihnya dibuat oleh praktisi pembelajaran Akuntansi sekaligus dipergunakan untuk uji coba fitur guru, penentuan kelayakan produk dalam penelitian pengembangan ini terbatas pada aspek materi, soal, bahasa, keterlaksanaan, perangkat lunak, desain pembelajaran, dan komunikasi visual. Pernyataan kelayakan media baru sebatas dilakukan oleh satu orang ahli media, satu orang ahli materi, dan satu orang praktisi pembelajaran. Media yang dikembangkan terbatas waktu dan kemampuan yang dimiliki oleh programmer, sehingga belum dapat dikatakan sempurna sebagai sebuah aplikasi. Uji coba instrumen angket hanya menggunakan uji terpakai dan uji coba lapangan hanya dilakukan sekali sehubungan dengan subjek penelitian akan melaksanakan Praktik Kerja Lapangan dalam jangka waktu yang cukup lama. Keterbatasan yang terakhir yakni pengembangan media hanya difokuskan kepada fungsi aplikasi, bukan kepada materi. 


\section{SIMPULAN DAN SARAN \\ Simpulan}

Berdasarkan hasil penelitian dan pembahasan, maka dapat diambil kesimpulan bahwa pengembangan aplikasi edukatif berbasis android dan desktop "Edcounting-App"menggunakan model pengembangan ADDIE yaitu analisis (analysis), desain (design), pengembangan (development), implementasi (implementation), dan evaluasi (evaluation). Kemudian, penilaian siswa kelas XI Akuntansi SMK Negeri 7 Yogyakarta terdiri dari 2 kelas yaitu, XI Ak 1 dan XI Ak 2 dengan total jumlah siswa 64 siswa hanya 54 siswa yang dapat hadir pada saat penelitian. Penilaian dari siswa kelas XI Ak 1 mengenai aplikasi edukatif berbasis android dan desktop "Edcounting-App" memperoleh nilai rata-rata seluruh aspek sebesar 3 yang masuk dalam kategori Layak, sedangkan XI Ak 2 memperoleh nilai rata-rata seluruh aspek sebesar 2,98 yang masuk dalam kategori Layak. Total keseluruhan penilaian siswa kelas XI Ak 1 dan XI Ak 2 dari semua aspek memperoleh nilai rata-rata sebesar 2,99. Berdasarkan penilaian ini, media dinyatakan Layak digunakan sebagai media pembelajaran Akuntansi. Terakhir, berdasarkan seluruh penilaian dari ahli media sebesar 3,44, penilaian dari ahli materi sebesar 3, penilaian dari praktisi pembelajaran Akuntansi sebesar 2,93, dan penilaian siswa kelas XI Ak SMK Negeri 7 Yogyakarta sebesar 2,99, maka aplikasi edukatif berbasis Android dan Desktop "EdcountingApp" Layak dipergunakan sebagai media pembelajaran Akuntansi Keuangan.

\section{Saran}

Berdasarkan kualitas media, kelemahan, dan keterbatasan penelitian yang telah dibahas sebelumnya, peneliti dapat memberikan beberapa saran pemanfaatan dan pengembangan media lebih lanjut sebagai berikut:

1) Aplikasi edukatif berbasis android dan desktop "Edcounting-App" sebaiknya digunakan guru dalam kegiatan belajar mengajar di luar sekolah, seperti untuk penugasan dan pemberian materi tambahan supaya siswa tidak hanya belajar pada saat jam KBM saja.

2) Aplikasi edukatif berbasis android dan desktop "Edcounting-App" sebaiknya digunakan siswa untuk belajar mandiri di rumah sehingga dapat menambah pemahaman terhadap materi yang dipelajari.

3) Aplikasi edukatif berbasis android dan desktop "Edcounting-App" perlu dikembangkan dari segi materi yang lebih luas lagi. Materi yang disajikan tidak hanya memuat satu kompetensi dasar (KD) saja, namun dapat dikembangkan dengan memuat materi yang lebih luas dan soal yang lebih banyak.

4) Aplikasi edukatif berbasis android dan desktop "Edcounting-App" berbasis Android perlu dikembangkan lebih lanjut dari segi fitur yang dimiliki.

5) Perlu adanya manajemen waktu yang lebih baik dalam mempersiapkan media yang dikembangkan, materi yang akan disajikan, dan terkait waktu penelitian.

\section{DAFTAR PUSTAKA}

Biddle, B. J., \& Rossi, P. H. (1966). The new Media and Education. Chicago: Aldine Publ.

Daryanto. (2013). Media Pembelajaran Peranannya Sangat Penting dalam Mencapai Tujuan Pembelajaran. Yogyakarta: Gava Media.

Endang Mulyatiningsih. (2013). Metode Penelitian Terapan Bidang Pendidikan. Bandung: Alfabeta.

Eko Putro Widoyoko. (2014). Evaluasi Program Pembelajaran. Yogyakarta: Pustaka Pelajar.

Nana Sudjana dan Ahmad Rivai. (2013). Media Pengajaran. Bandung: Sinar Baru Algensindo Offset.

Romi Satria Wahono. (2006). "Aspek dan Kriteria Penilaian Media
Pembelajaran". 
http://romisatriawahono.net/2006/0 6/21/aspek-dan-kriteria-penilaianmedia-pembelajaran/.

Stephanus Hermawan S. (2012). Mudah Membuat Aplikasi Android. Yogyakarta: Andi Offset.

Sugiyono. (2013). Metode Penelitian Pendidikan Pendekatan Kuantitatif, Kualitatif, dan $R \& D$. Bandung: Alfabeta.

Sumadji P. (2006). Kamus Istilah Ekonomi. Gama Press.

Suharsimi Arikunto. (2010). Prosedur Penelitian Suatu Pendekatan Praktik. Jakarta: Rineka Cipta. 